\title{
THE FUTURE OF THE LAW IN AFRICA
}

\begin{abstract}
Record of the Proceedings of the London Conference, 28 th December, 1959-8th January, 1960. Under the Chairmanship of The Rt. Hon. LORD DENNING, Edited on behalf of the Conference by A. N. ALLOT'T, M.A., Ph.D., Reader in African Law at the School of Oriental and African Studies, University of London; Managing Editor of The Journal of African Law.
\end{abstract}

The Conference was attended by a representative gathering of those actively concerned with the administration of justice and the development of law in Africa; the majority present came from Commonwealth countries, but delegations from outside the Commonwealth were also present, as well as English judges, academic lawyers and others interested. It was essentially a technical conference, not designed to recommend policy but rather to provide an authoritative study of the problems from a professional point of view, so as to supply a background which might be of assistance to governments in formulating their policies on the future of law.

The Record sets out a summary of the proceedings and the conclusions reached. Altogether it runs to $5^{8}$ pages.

"This book is essential reading for anyone connected with African Law, but it should appeal to a wider audience of those interested in the orderly development of our African colonies and territories."

The Solicitors' Journal.

BUTTERWORTHS, 88 Kingsway, London, W.C.2

Showroom : 11-12 Bell Yard, Temple Bar, W.C.2 


\section{BUTTERWORTH BOOKS}

YARDLEY'S INTRODUGTION TO BRITISH CONSTITUTIONAL LAW. By D. C. M. YARdLEy, LL.B.(BIRM.), M.A., D.PHIL.(OXON.), Barrister-at-Law, Fellow of St. Edmund Hall, Oxford.

The main object of this new book is to meet the needs of university students in their study of constitutional law, and students who are reading for Part I of the Bar examination, but it will also be of great assistance to anyone requiring a certain amount of knowledge of the law of the Constitution.

The author gives a brief composite sketch of the ficld that any student of the subject must cover and has kept footnotes and authorities to the minimum.

\section{ALLOTT'S ESSAYS IN AFRICAN LAW with} special reference to the Law of Ghana. By A. N. Allott, м.A., PII.D., Reader in African Law at the School of Oriental and African Studies, University of London.

". . . it is a comprehensive survey of the laws and customs of dependent and emerging independent countries in Africa. The sympathetic approach to the exposition of legal systems which have as yet not received the attention they deserve is both appealing and instructive."-Law Fournal.

HAYDON'S LAW AND JUSTIGE IN BUGANDA. By E. S. HAYDON, B.A., Barrister-at-Law, formerly Judicial Adviser, Buganda.

Besides supplying lawyers with a complete guide to the law in Buganda, this work is a fascinating study of tribal customs. Mr. Haydon has a profound knowledge of his subject, and carries both practitioner and layman along the rutted tracks of Constitution, The Law of Persons, Succession, Property, Mercantile Law and the Law of Wrongs and Procedure with the minimum of effort.

KERR'S NATIVE LAW OF SUCGESSION IN SOU TH A FRICA. By A. J. KerR, B.A., LL.M., Advocate of the Supreme Court of South Africa; Member of the Grahamstown Bar; Senior Lecturer in Law, Rhodes University.

Many difficulties are encountered when Native estates require to be administered and there has long been a need for a detailed and comprehensive work dealing with the Native Law of Succession in all its aspects. This work, covering all statutes of general application and the law of the Nguni tribes of the Cape and Natal in particular, provides a clear and detailed exposition of principle together with numerous references to, and quotations from, authority. It should prove to be of assistance to judicial officers, administrators, legal practitioners and students. Tables of Cases and of Statutes allow quick and easy reference to authority.

BUTTERWORTHS, 88 Kingsway, London, W.C.2 Showroom: 11-12 Bell Yard, Temple Bar, W.C.2 